\title{
Myxomycetes of Maharashtra: two new species of Diderma Pers
}

\author{
Mishra RL ${ }^{1}$, Phate $\mathbf{P V}^{1}$ and Ranade $\mathrm{VD}^{2}$ \\ ${ }^{1}$ Department of Botany, Janta Sikshan Mandal College, Alibag, Raigad- 402 201, Maharashtra, India \\ ${ }^{2}$ Department of Botany, Abasaheb Garware College, Pune, Maharashtra, India \\ Email: rlmishra9@gmail.com
}

Mishra RL, Phate PV, Ranade VD 2013 - Myxomycetes of Maharashtra: two new species of Diderma Pers. Mycosphere 4(5), 865-869, Doi 10.5943/mycosphere/4/5/2

\begin{abstract}
The present paper provides the description and illustrations of two new species of Diderma (D. non-columellata sp. nov. and D. physarinum sp. nov.) that are characterized by the absence of columella in the first instance and the presence of a large columella bearing a number of peg-like protuberances running through the sporangial cavity up to the peridium in the second instance. The latter condition is similar to what is found in the genus Physarina respectively.
\end{abstract}

Key words - columella - peg like protuberances - peridium - Physarina

\section{Introduction}

Diderma is one of the genera in the family Didymiaceae of the order Physarales and is represented by more than 75 species distributed throughout the world. The genus is characterized by having fruiting bodies with a typically double layered peridium of either a calcareous or cartilaginous nature and only rarely single or triple peridium. The other characters include the usually well developed and calcareous columella, the limeless capillitial threads and dark coloured spores. However, the two new species of the genus described herein are unique in their characters.

\section{Materials \& Methods}

\section{Collections}

The two new species of Diderma were collected from localities such as like Kankeshwar, Mahabaleshwar and Panchgani in the western portion of Maharashtra, India. Diderma non-columellata was collected on dead and living leaves from Kankeshwar, Mahabaleshwar and Panchgani, whereas D. physarinum was collected on living moss and lichens from Mahableshwar. These forms along with the substratum upon which they occur were immediately glued in plastic boxes and labeled with information that included the accession number, botanical name, habitat, locality, date, name of the collector etc. After bringing the material to the laboratory, the boxes were kept open for air dry in order to remove moisture so as to avoid the invasion of the other organism. 


\section{Slide Preparations}

For microscopic studies, temporary slides were prepared. Water mounts were found to be best for the actual detection of the colours while the semi permanent slides were prepared by using Amann's fluid in place of glycerin. The slides were sealed with the help of wax. The "Erma" camera lucida were prepared illustrating the habit, type of fruiting body and character of spores and capillitium at the stage level using different combination of objectives and eyepieces. Measurements were taken by using 6x Ernst Wetzler ocular and different objective combination. Photomicrographs of slides were also taken by using Ernst-Leitz Wetzler unit of photomicrography and habits photographs by Zoom camera (MA IV b Leitz Wetzler Co. Germany) to have more realistic views.

\section{Identification}

Literatures such as Lister G (1925); Lodhi (1934); Martin and Alexopoulos (1969); Ainsworth and Sussman (1973); Nannenga - Bremekamp (1974); Olive (1975); Thind (1977) and Lakhanpal \& Mukerji (1981) were referred to for identification of species.

\section{Results}

\section{Taxonomic Descriptions}

Diderma non-columellata Mishra and Ranade sp. nov.

Figs. 1A-D AMH-9583

Fructifications sporangiate, sporangia densely crowded, subpulvinate, sessile, white to ashy white, calcareous, $0.35-0.7 \mathrm{~mm}$ in diameter, rough due to wrinkles or smooth, white thin, dehiscence irregular, columella absent, capillitium thread, threads brown at the base, fading to colourless towards the apex running through sporangial cavity from its base to the apex and attaching with the sporangial wall above, somewhat branched, marked with small bead like thickenings, spores deep brown in mass, violaceous brown in mass, violaceous brown by transmitted light, globose, distinctly and regularly spiny, 7.5-8 $\mu$ in diameter.

On dead leaves, Panchgani, Sept. 14, 1975; dead leaves, Kankeshwar, Aug. 2, 1977; Mahableshwar, Sept. 18, 1977, Sept. 10, 1978.

The diagnostic feature of $D$. non-columellata is the absence of columella. Authors think that this feature is the most remarkable because such character is probably not seen in any other species of Diderma. In case, the columella is found to be absent in some species, at least it must be represented by rudimentary thickened base of fructifications but in the present species even that is not observed.

Of the described species of Diderma, D. cinereum is probably most closely related to Diderma non-columellata. Externally the two species are indistinguishable. The hypothallus in both species are indistinct; fructifications of both consist of sporangia of crowded and sessile nature. Nevertheless, both species can be distinguished on disparities of the following characters. In $D$. cinereum, sporangia are sub-globose, pearl grey and $0.3-0.5 \mathrm{~mm}$ in diameter; peridium appearing single and crustose; columella is white, hemispheric to sub-globose; capillitial threads are without nodular swelling and spores are minutely warted and $9-11 \mu$ in diameter. In Diderma noncolumellata the sporangia are sub-pulvinate, white or grayish white and $0.32-0.7 \mathrm{~mm}$ in diameter; peridium is typically single and non-crustaceous; columella is absent; capillitial threads are with nodular thickenings and spores are distinctly and regularly spiny and 7.5-8.0 $\mu$ in diameter. 


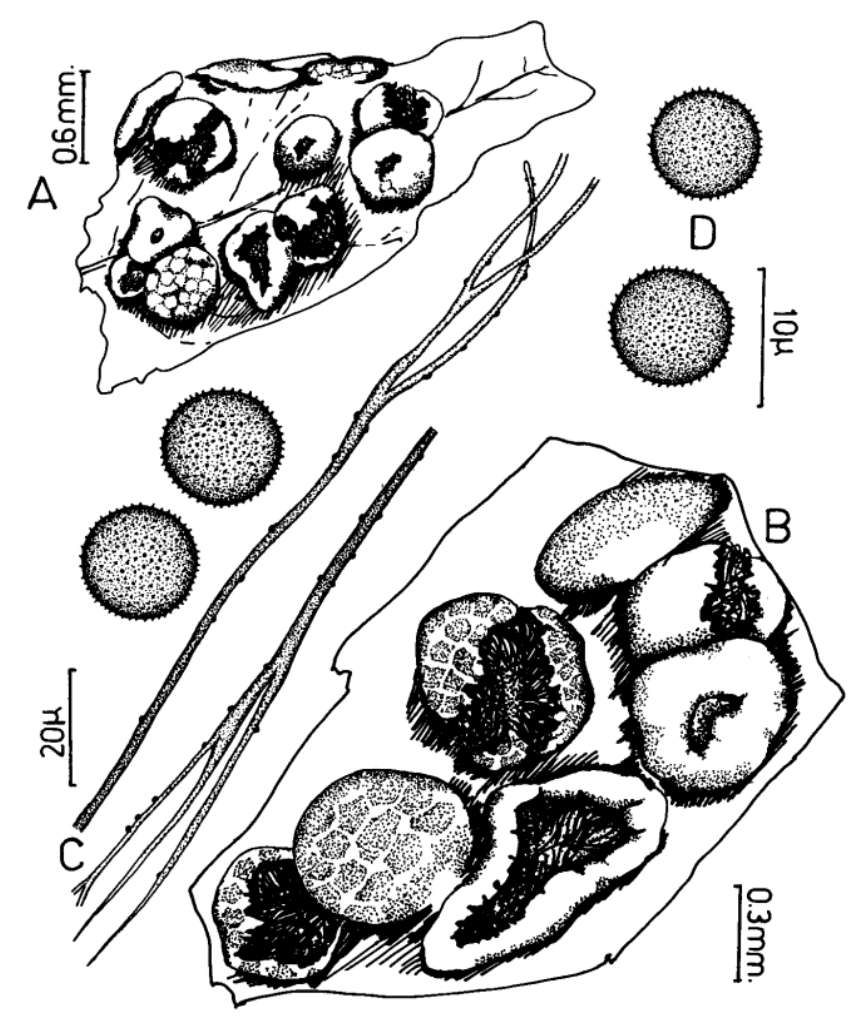

Fig. 1 - Camera lucida sketch of Diderma non- columellata. A. Fruiting body on dead leaves; B. Enlarged view of fruiting body; C. Capillitium; D. Spores.

Diderma physarinum Mishra and Ranade sp. nov.

Figs. 2 A-D AMH-9586

Fructification sporangiate or plasmodiocarpus, gregarious or scattered, almost sessile, globose or sub-globose, white, calcareous, occasionally limeless and dark at the base, slightly rugose, mottled, $0.5-1 \mathrm{~mm}$ in diameter; hypothallus indistinct; stalk, if present, represented by the base of the sporangium; peridium single, brittle, rugose, white, upper surface with dimples, dehiscence irregular above, somewhat stellate below; columella white, calcareous, quite large, in some fruiting occupying half of the sporangial cavity up to the peridium; capillitium noncalcareous, threads flattened, dark brown, branching and anastomosing with membranous expansions, fading to brownish at the base, arising from columella as well as from peg-like protuberances; spores blackish in mass, violaceous brown by transmitted light, globose, irregularly warted with clusters of darker warts at few places, 12-14 $\mu$ in diameter.

On living mosses and lichens, Mahabaleshwar, Sept. 09, 1978

This interesting myxomyceteous form although known from only one locality, there is no doubt that it represents an undescribed species.

The most unusual characteristic of $D$. physarinum is the large columella which bears number of peg-like protuberances running through the sporangial cavity up to the peridium. Such protuberances are seen in the genus Physarina on the outer peridium. As they are present on the columella on the present species the name is referred as $D$. physarinum.

The presence of dimple on the outer surface of the peridium is possibly due to the attachment of protuberances on the inner side of the peridium. This also indicates that peridium is typically single.

D. physarinum seems to be related to D. radiatum (L.) Morgan. Both species have scattered, globose, mottled, almost sessile sporangia, rugose peridium, irregular dehiscence above and stellate below, large calcareous columella and brown, branched and anastomosed capillitial threads. 


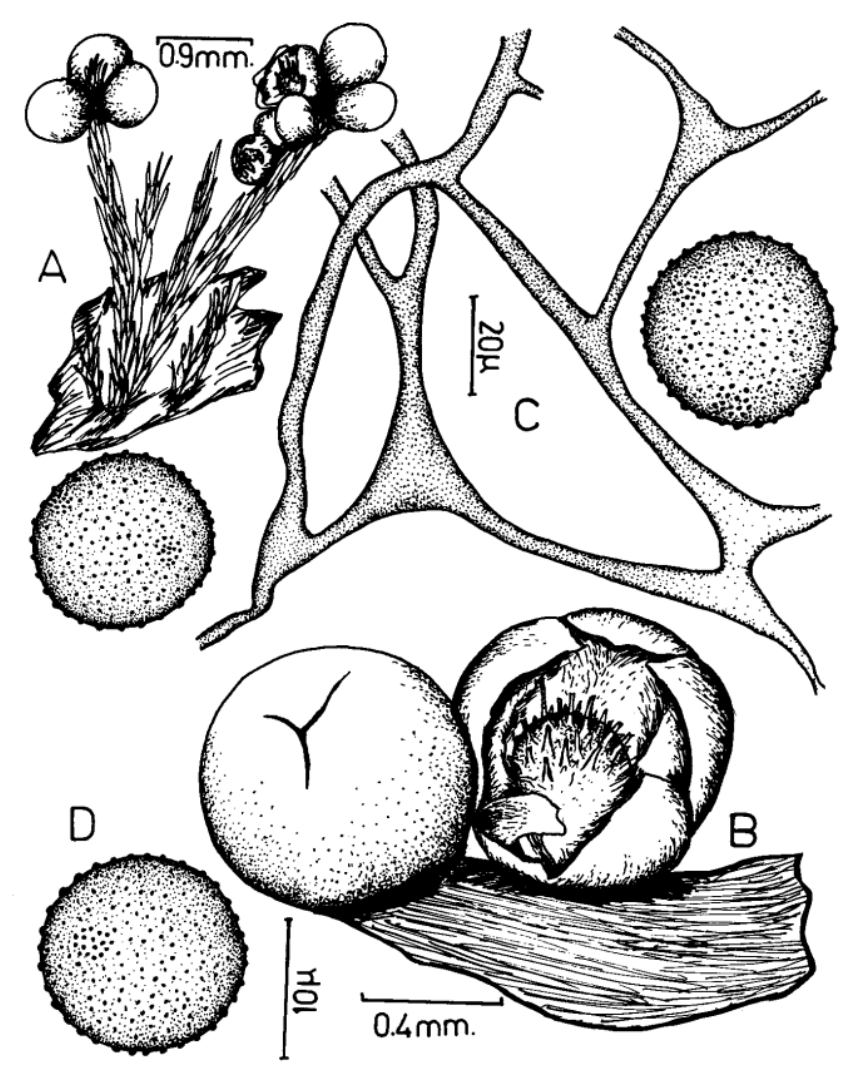

Fig. 2 - Camera lucida sketch of Diderma physarinum A. Fruiting body on decaying leaf; B. Enlarged view of fruiting body; C. Capillitium; D. Spores.

Nevertheless, other characters of $D$. radiatum are not evident of $D$. physarinum. They are as follows: The fructifications are of only sporangial type and not the plasmodiocarpus type; sporangia are umblicate below; peridium is double; columella hemispheric or sub-globose, pale cream colored to orange or reddish brown without peg-like protuberances and the spores are purplish brown by transmitted light, without cluster of darker warts, measuring 9-12 $\mu$ in diameter.

\section{Herbarium}

The type specimens have been deposited in Maharashtra Association for the Cultivation of Science, Agharkar Research Institute at Ajrekar Mycological Herbarium, Pune, Maharashtra.

\section{Acknowledgements}

The authors are very much thankful to the colleagues in the department of Botany of J. S. M. College, Alibag for their benevolent help in the laboratory. Authors are also thankful to Dr. Mannikam of De Nabili College, Pune for the Latin diagnosis.

\section{References}

Ainsworth GC, Sussman AS. 1973 - The Fungi an Advanced Treatise. Vol IV B, Academic Press, New York and London, XV+504.

Alexopoulos CJ. 1969 - The Experimental approach to the taxonomy of the Myxomycetes. Mycologia 61 219-239. 
Chin HL, Jong HC. 2011 - Myxomycetes of Taiwan XXI. The genus Diderma. Taiwania 56 (2) $118-124$.

Kornerup A, Wanscheu JH. 1967 - Methuen hand book of colors. Methuen and Co Ltd London 243.

Lakhanpal TN, Mukerji KG. 1981 - Indian Myxomycetes. J Cramer Germany 530.

Lister G. 1925 - Monograph of Mycetozoa. $3^{\text {rd }}$ Edition British Museum (Nat. Hist.) London 296.

Lodhi SA. 1934 - Indian Slime moulds. University of Punjab Lahore 34+ Pl VIII.

Martin GM, Alexopoulos CJ. 1969 - The Myxomycetes University of Iowa Press Iowa London IX $+561 \mathrm{Pl}$. XLI.

Nannenga Bremekamp NE. 1974 - De Nederlandse Myxomyceten. Koninkijke Nederlandse Natuurhistorische Vereniging 440.

Olive LS. 1975 - The Mycetozoa. Academic Press London New York IX+ 293.

Thind KS. 1977 - The Myxomycetes in India. ICAR, New Delhi, 452. 